\title{
ASPECT OF REPRODUCTIVE BIOLOGY OF PARACHANNA OBSCURA, GUNTHER 1861 IN A SOUTHWESTERN NIGERIAN RESERVOIR
}

\author{
O. KAZEEM KAREEM ${ }^{1}$, A. NURUDEEN OLANREWAJU ${ }^{2} \&$ O. ORISASONA ${ }^{3}$ \\ ${ }^{1}$ Department of Aquaculture and Fisheries Management, University of Ibadan, Nigeria. \\ ${ }^{2}$ Federal College of Freshwater Fisheries Technology, Nigeria. \\ ${ }^{3}$ Department of Animal Sciences, Obafemi Awolowo University, Nigeria.
}

\begin{abstract}
African snakehead (Parachanna obscura) is a highly valued freshwater fish species in Nigeria, but its availability for economic and nutritional benefits is being threatened as a result of overdependence on wild source. Effort at bringing it to culture is, however, being limited by paucity of information on its biology among other challenges. Therefore, key aspects of the reproductive biology of this species were investigated as a prelude to artificially propagate it. 688 live samples comprise of 394 females $(12.6-45.0 \mathrm{~cm} \mathrm{TL})$ and 294 males $(12.8-41.6 \mathrm{~cm}$ TL) were fortnightly obtained in Eleyele Lake between November 2014 and October 2016 from fishermen majorly using longline, cast nets and gillnets of various mesh sizes. Morphometric parameters of fish were taken, and each sample dissected for sex identification following standard method. The maturation stages were analysed using macroscopic and standard histological techniques. The sex ratio of samples varied significantly $(p<0.05)$, with 1.34 females for every male. Five stages of oogenesis and three stages of spermatogenesis were obtained from samples analysed. Mean gonadosomatic index were significantly higher in May $(2.26 \pm 0.86 \%)$, June $(2.08 \pm 0.80 \%)$ and January $(1.98 \pm 0.77 \%)$ for female samples and in June $(0.18 \pm 0.06 \%)$ and December $(0.21 \pm 0.06 \%)$ for male, implying peaks of gonadal development for the sexes. Length at first maturity calculated was $26.6 \mathrm{~cm}$ for males and $25.8 \mathrm{~cm}$ for females. The diameter of ova, however, varies from 0.60 to $1.42 \mathrm{~mm}$. Absolute fecundity ranged between 336 (at $20.5 \mathrm{~cm}$ total length) and 7,033 (at 36.7 $\mathrm{cm}$ total length). The relationship between fecundity and total length, weight, ovary length and ovary weight was linear and positive. This research provides key information necessary for artificial propagation of P. obscura.

Keywords: African snakehead (Parachanna obscura), Eleyele Lake, fecundity, gonadosomatic index, gonad histology, reproduction, morphometric parameters, ova diameter, sex ratio, size at maturity.
\end{abstract}

\section{INTRODUCTION}

Snakehead fish species constituted a significant component of catches in most freshwater bodies of Asia and Africa. 35 different species have been reported in Asia as against three species so far identified in Africa (CIFA [1]). In both continents, Channids are of considerable economic importance as food and aquarium fish. Parachanna obscura (Gunther) and Parachanna africana (Steindachner) are the two available species in West Africa (Syndenham [2]). Snakehead culture is one of the fastest growing aquaculture industries in Asia (Marimuthu et al. [3]); however, the intensive culture of snakeheads is yet to be developed in Africa. African snakehead ( $P$. obscura) has long been considered as a good candidate for aquaculture (Kpogue et al. [4]). Successful domestication of any fish species demands a thorough knowledge of its reproductive biology (Malhotra et al. [5]). Studies on reproductive biology is a basic requisite for better conservation and management strategies of fishery resources (Muchlisin et al. [6]), for examination of basic life history and for evaluating the impacts of environmental variability on the dynamics of fish populations (Schlosser [7]). Information on the reproductive system is also essential for the development of the commercial aquaculture of an aquatic species. For any meaningful progress to be achieved in artificial 
propagation, basic information on reproductive biology of the species must be available. Roja [8] stated that studies on reproduction, including the assessment of maturation cycle, size at first maturity, sex ratio, spawning periodicity, fecundity and reproductive load of a fish species, permit quantification of the reproductive capacity of individual fish which are essential for rational and sustainable management of fisheries. Although few studies on reproductive biology of P. obscura had been conducted in Nigeria (Odo et al. [9]; Isangedighi and Umoumoh [10]; Olurin and Savage [11]), there exist no such documented information on Eleyele Lake. There is also paucity of information on stages of gonad development and histology of P. obscura. Hence, this study investigates the seasonal changes in the histology of the gonads and other reproductive indices.

\section{MATERIALS AND METHODS}

Samplings were caught on monthly basis between November 2014 and October 2016 in the Eleyele reservoir (Fig. 1), with about 153 hectare surface area in the southwestern part of Nigeria. Temperature and $\mathrm{pH}$ ranged between 22.0 and $32.0^{\circ} \mathrm{C}$ and between 5.6 to 8.5, respectively, and the average values ( \pm standard deviation) were $26.6 \pm 0.3^{\circ} \mathrm{C}$ and $7.1 \pm 0.5$, respectively, in the reservoir. Average depth was $5.17 \pm 1.94 \mathrm{~m}$. The lake experiences both dry and rainy seasons typical of tropical environment. Samples were collected by using the cast nets, long line and trap. Traps and long lines were located under macrophytes and set up at five different locations in the reservoir. They were usually set twice daily, i.e. morning and evening. Cast net was thrown daily usually early in the morning and evening time. Basically, samples were collected in early hours (0700 and 0900 hours) and late in the evening (1700 and 1800 hours) in ice-box for later measurements in the laboratory. Body lengths and weight were measured to the nearest $0.1 \mathrm{~cm}$ and $0.1 \mathrm{~g}$, respectively. After dissection, sex and maturity were determined by macroscopic examination of the gonads. The monthly

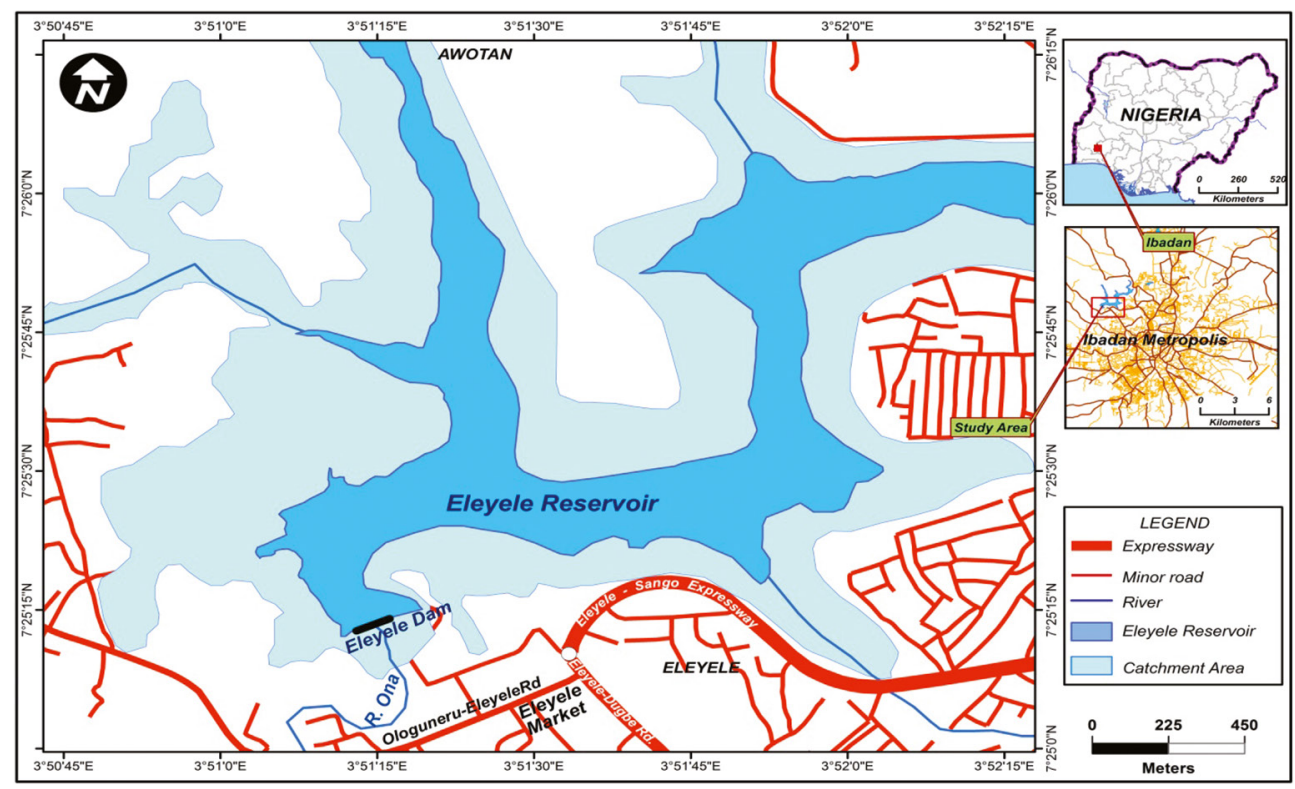

Figure 1: Map of the Eleyele Reservoir. 
gonadosomatic index (GSI) was calculated as: GSI= (gonad weight/ total fresh weight of fish) $\times 100$ (Marino et al. [12]). The proportion of the two sexes relative to one another was used to calculate the sex ratio. Histology was observed following histological techniques (Bancroft and Gamble [13]), and the stages of gonad development were classified as immature, developing, mature, ripe and spent (Nunez and Duponchelle [14]). The lengths at first maturity $\left(L_{\mathrm{m}} 50\right)$ were estimated for both sexes (Suresh et al. [15]). The fecundity was estimated by counting the number of mature ova (opaque and larger in size) from known weights of sub-samples collected from the anterior, posterior and middle portions of the ovaries and calculating the total number of mature ova (Farmer et al. [16]). To determine the spawning and breeding periodicity, egg diameter (width) progression was recorded monthly according to Douglas [17]. Measurements of ova diameter were taken by an ocular micrometre (Mitutoyo, APB-ID. Error $=0.001 \mathrm{~mm}$ ). Data were analysed using descriptive statistics, Chisquare, multiple linear regression and ANOVA at $\alpha_{0.05}$.

\section{RESULTS}

A total 688 P. obscura samples comprising 294 males and 394 females were studied. Monthly catch percentages of both sexes were given (Table 1). The estimated ratio was in favour of females (1.34 \%: $\left.1 \delta^{\top}\right)$ and the difference between the sexes was highly significant $\left(\chi^{2}=14.5\right.$, $\mathrm{df}=1, p<0.05$ ). The monthly sex ratio ( $\left(\delta^{\star}\right)$ was found to be biased towards females, but only significant in November $\left(\chi^{2}=6.04, \mathrm{df}=1, p<0.05\right)$. The GSI shows highly significant differences for both sexes (ANOVA, $p<0.05$ ) (Table 2). The maximum values in males appear between November to January and May to October with two peaks in December $(0.21 \pm 0.06 \%)$ and June $(0.18 \pm 0.06 \%)$. The minimum values were obtained between February to April and in October. However, females show little or no seasonality in GSI value as compared to males. The higher index values in females occurred between November to

Table 1: Monthly catch proportion of Parachanna obscura.

\begin{tabular}{lcccccc}
\hline Month & Total sample & Males & Females & (M:F) & Proportion of males & $\left(x^{2}\right)$ \\
\hline November & 73 & 26 & 47 & 1.81 & 0.36 & $6.04^{*}$ \\
December & 59 & 28 & 31 & 1.11 & 0.48 & 0.15 \\
January & 63 & 24 & 39 & 1.63 & 0.38 & 3.57 \\
February & 42 & 17 & 25 & 1.47 & 0.40 & 1.52 \\
March & 54 & 22 & 32 & 1.45 & 0.41 & 1.85 \\
April & 52 & 26 & 26 & 1 & 0.50 & 0.00 \\
May & 52 & 20 & 32 & 1.60 & 0.38 & 2.77 \\
June & 58 & 27 & 31 & 1.15 & 0.47 & 0.28 \\
July & 65 & 30 & 35 & 1.17 & 0.46 & 0.39 \\
August & 53 & 21 & 32 & 1.52 & 0.39 & 2.28 \\
September & 58 & 27 & 31 & 1.15 & 0.47 & 0.28 \\
October & 59 & 26 & 33 & 1.27 & 0.44 & 0.83 \\
Overall & 688 & 294 & 394 & 1.34 & 0.43 & $14.5^{*}$ \\
\hline
\end{tabular}

${ }^{*}$ Significant at $5 \%$ level $(p>0.05)$. 
Table 2: Gonadosomatic index (GSI) for male and female $P$. obscura between November 2014 and October 2016.

\begin{tabular}{|c|c|c|c|c|c|c|c|c|}
\hline \multirow[b]{2}{*}{ Month } & \multicolumn{4}{|c|}{ Male } & \multicolumn{4}{|c|}{ Female } \\
\hline & $n$ & $\begin{array}{l}\text { Mini- } \\
\text { mum }\end{array}$ & $\begin{array}{l}\text { Maxi- } \\
\text { mum }\end{array}$ & Mean \pm SD & $n$ & $\begin{array}{l}\text { Mini- } \\
\text { mum }\end{array}$ & $\begin{array}{l}\text { Maxi- } \\
\text { mum }\end{array}$ & Mean \pm SD \\
\hline November & 07 & 0.11 & 0.20 & $0.15 \pm 0.04_{a}$ & 11 & 0.46 & 1.91 & $1.05 \pm 0.44_{\mathrm{a}}$ \\
\hline December & 05 & 0.14 & 0.28 & $0.21 \pm 0.06_{b}$ & 11 & 0.35 & 2.80 & $1.36 \pm 0.63 \mathrm{a}$ \\
\hline January & 07 & 0.09 & 0.22 & $0.15 \pm 0.05$ & 11 & 1.10 & 3.15 & $1.98 \pm 0.77_{b}$ \\
\hline February & 05 & 0.08 & 0.13 & $0.10 \pm 0.02_{a}$ & 11 & 0.76 & 1.59 & $1.13 \pm 0.27 \mathrm{a}$ \\
\hline March & 07 & 0.06 & 0.19 & $0.11 \pm 0.03$ & 11 & 0.49 & 1.38 & $0.79 \pm 0.30 \mathrm{a}$ \\
\hline April & 07 & 0.09 & 0.13 & $0.11 \pm 0.02_{a}$ & 11 & 0.40 & 1.88 & $1.18 \pm 0.43_{\mathrm{a}}$ \\
\hline May & 07 & 0.11 & 0.20 & $0.15 \pm 0.04_{\mathrm{a}}$ & 11 & 0.51 & 3.36 & $2.26 \pm 0.86_{b}$ \\
\hline June & 07 & 0.06 & 0.23 & $0.18 \pm 0.06_{b}$ & 11 & 0.33 & 3.06 & $2.08 \pm 0.80_{b}$ \\
\hline July & 07 & 0.07 & 0.15 & $0.13 \pm 0.04_{a}$ & 11 & 0.29 & 2.55 & $1.27 \pm 0.74_{\mathrm{a}}$ \\
\hline August & 07 & 0.07 & 0.20 & $0.12 \pm 0.04_{a}$ & 11 & 0.36 & 2.94 & $1.22 \pm 0.85_{\mathrm{a}}$ \\
\hline September & 07 & 0.12 & 0.19 & $0.15 \pm 0.03_{\mathrm{a}}$ & 11 & 0.32 & 1.97 & $1.04 \pm 0.52_{\mathrm{a}}$ \\
\hline October & 07 & 0.05 & 0.15 & $0.11 \pm 0.04_{a}$ & 11 & 0.33 & 1.93 & $1.09 \pm 0.55$ \\
\hline Overall & 80 & 0.05 & 0.28 & $0.13 \pm 0.05$ & 132 & 0.29 & 3.36 & $1.37 \pm 0.75$ \\
\hline
\end{tabular}

February and April to October with highest values obtained in May, June and January. Also, the overall mean GSI for males and females was $0.13 \pm 0.05 \%$ and $1.37 \pm 0.75 \%$, respectively. These cyclic changes in GSI indices are indication that the reproductive activity in $P$. obscura could be all year round. The length at first sexual maturity $\left(L_{\mathrm{m}} 50\right)$ of $P$. obscura was obtained as $26.6 \mathrm{~cm}$ and $25.8 \mathrm{~cm}$ for males and females, respectively (Fig. 2). Five maturation stages were discerned as shown in Table 3. However, stage I and stage $\mathrm{V}$ were not observed in male samples (Figs. 3 and 4). As in most teleost, the gonads in male and female P. obscura are paired, elongated organs, located in the dorsal portion of the body cavity. The size and extent of occupancy of the body cavity were found to vary with size and level of maturity of the fish. The length, width and colour of gonads were observed to be changing as maturity progresses and could be due to heavy vascularization.

In the female, the colour turned yellowish-orange on maturation and golden yellow when were ready to spawn (stages III and IV) (Fig. 4), but no such colour changes occur in males (Fig. 4). The monthly dynamics in percentage of male and female at each stage of maturation (Fig. 5) showed ripe (stage IV) and spent (stage V) for females between November to January and June to July, with higher frequencies in November and December. This probably indicates the reproductive period of the species. Immature ovaries (stage I) occur more frequently after December and are most abundant in February (54.55\%), April (100.00\%) and May $(63.64 \%)$ signalling cessation in spawning. Females with maturing ovaries (stage II) were absent between November-December and April-May. The highest percentage of maturing ovaries was found in August (45.45\%) and September (45.45\%). Ripening (stage III) females started appearing in May and reached a peak in October (54.55\%). From October onwards, the ripening individuals showed a sharp decline and peaked again in March (63.64\%). In male, maturing (stage II) and ripening (stage III) appeared in all months except in January, 

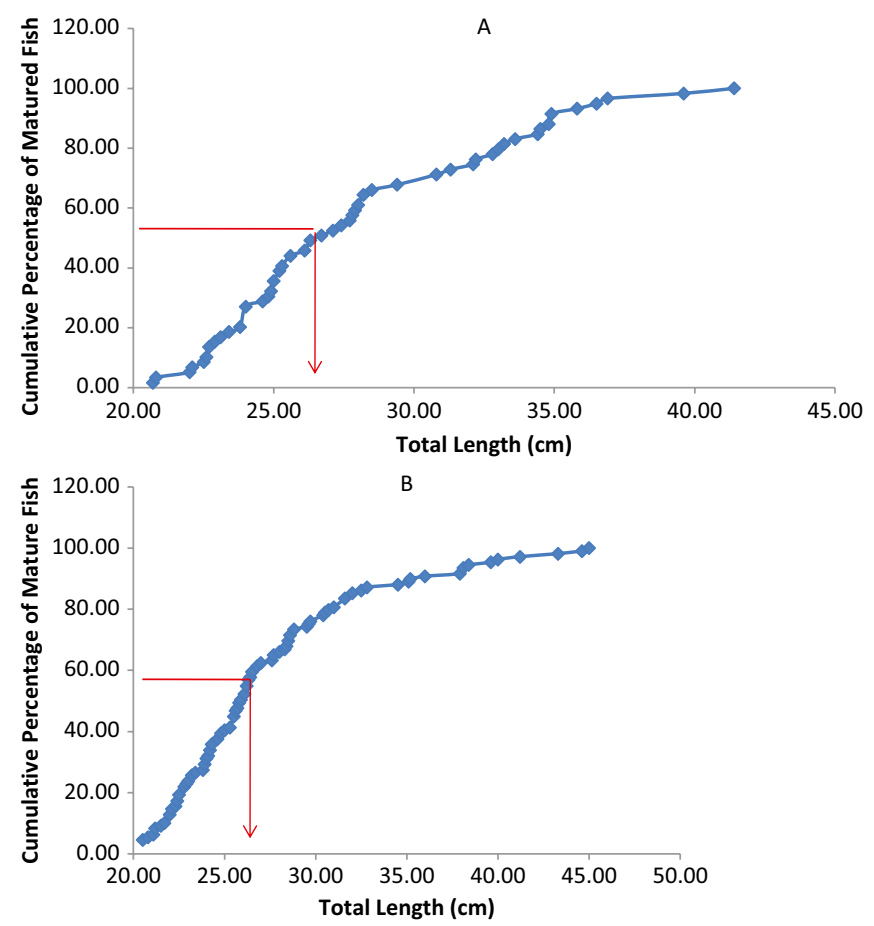

Figure 2: Cumulative relative frequency of the length at first maturity P. obscura in different size groups collected from Eleyele Lake: (A) Male (B) Female, the 50\% maturity is marked by thin horizontal line.

June and February. Ripe males were, however, absent in February, April and August. The highest frequencies of ripe male occur in June (75.0\%) and January (71.43\%). Meanwhile, no immature (stage I) and spent (stage V) testes were found during study.

The absolute fecundity varied from 336 to 7,033 eggs for samples with total length 20.5 to $36.7 \mathrm{~cm}$ (Table 4). Also, the mean number of eggs per gram gonad weight was 308 eggs. The average fecundity value for different size groups increases as fish size increases (Table 4). The relationships between fecundity (F), total length (TL), total body weight (BW), weight of ovary (OW) and length of ovary (OL) are depicted in Table 5. The logarithm of fecundity and morphometric parameters above revealed a linear positively correlated relationship with high predictive value. Ovary weight was, however, negatively correlated with total length and body weight. The diameter of ova, however, varies from 0.60 to $1.42 \mathrm{~mm}$.

\section{DISCUSSION}

In this study, the sex ratio was in favour of female in most part of the two seasons of the year. Also, monthly sex ratio was significantly different from the expected 1:1. This result is in conformity with the earlier report on P. obscura in Anambra River (Odo et al. [9]) and River Oshun (Olurin and Savage [11]). However, higher male to female ratios were reported by Odo et al. [18] for Heterotis niloticus. The GSI of both males and females in this study followed same trend of low GSI within February-April and September-November. These months are concomitant with a period of early development of gonads and spent fishes (Roja 
Table 3: Description of macroscopic and microscopic characteristics of each maturity stage of $P$. obscura gonads.

\begin{tabular}{lll}
\hline Stages & Testes & Ovaries \\
\hline $\begin{array}{l}\text { Stage I } \\
\text { (immature) }\end{array}$ & Not discovered & $\begin{array}{l}\text { The ovaries are small, transparent to } \\
\text { translucent with inconspicuous vasculari- } \\
\text { zation. Ovary shows numerous oocytes in } \\
\text { vitellogenic stages. }\end{array}$ \\
$\begin{array}{ll}\text { Stage II } \\
\text { (maturing) }\end{array}$ & $\begin{array}{l}\text { Testes were small, opaque and } \\
\text { creamy white in colour. It is } \\
\text { slightly thickened and shows cyst } \\
\text { Ovaries become slightly larger, thicker } \\
\text { and opaque and are orange-pale in colour. }\end{array}$ & $\begin{array}{l}\text { Ovary shows many oocytes in vitelline } \\
\text { stages. }\end{array}$ \\
$\begin{array}{l}\text { Stage III } \\
\text { (ripening) }\end{array}$ & $\begin{array}{l}\text { Testes were slightly enlarged and } \\
\text { whitish in colour. It shows lob- } \\
\text { ules and cysts of spermatogonic } \\
\text { development. }\end{array}$ & $\begin{array}{l}\text { Ovaries become turgid and deep orange } \\
\text { in colour. Ovary shows numerous oocytes } \\
\text { in pre-vitelline stages and vitelline stages. }\end{array}$ \\
$\begin{array}{l}\text { Stage IV } \\
\text { (ripe) }\end{array}$ & $\begin{array}{l}\text { Testes are fully developed with } \\
\text { turgid fringes and milky-whitish } \\
\text { in colour. It shows seminiferous } \\
\text { lobules with cysts containing stages } \\
\text { of spermatogenic development. } \\
\text { Not discovered. }\end{array}$ & $\begin{array}{l}\text { Ovaries are turgid and golden yellow in } \\
\text { colour with a large number of translucent } \\
\text { ings. It shows matured oocytes said to be }\end{array}$ \\
& $\begin{array}{l}\text { The ovaries are flaccid and shrinked with } \\
\text { Stage V } \\
\text { (spent) }\end{array}$ & $\begin{array}{l}\text { The dull yellow colour. Histologically, the } \\
\text { ovary shows predominately degenerate } \\
\text { oval and pre-vitelline ovum. }\end{array}$ \\
\hline
\end{tabular}

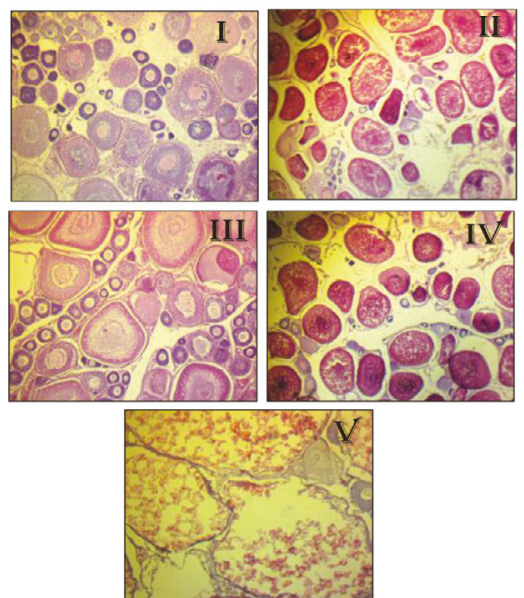

(A) Ovary

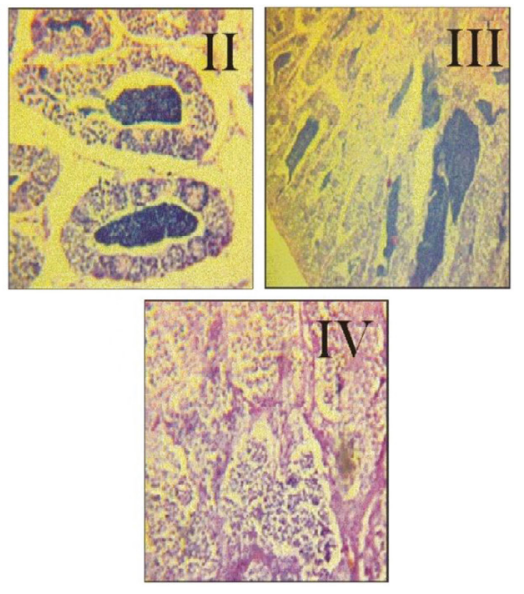

(B) Testis

Figure 3: Photomicrograph of ovary (A) and testis (B) at different stages of maturation. 

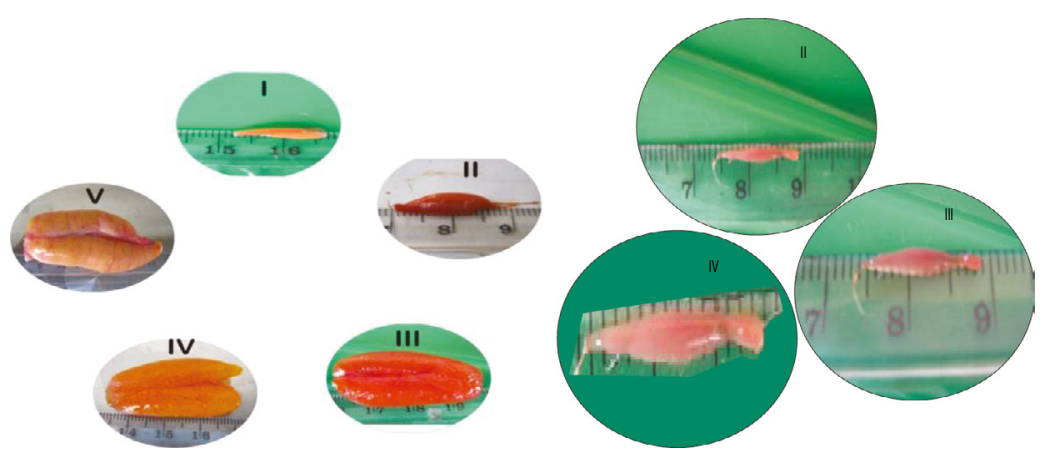

Figure 4: Gonad developmental stages: (a) Development stages of five ovaries in female P. obscura and (b) three testicular development stages in male P. obscura.
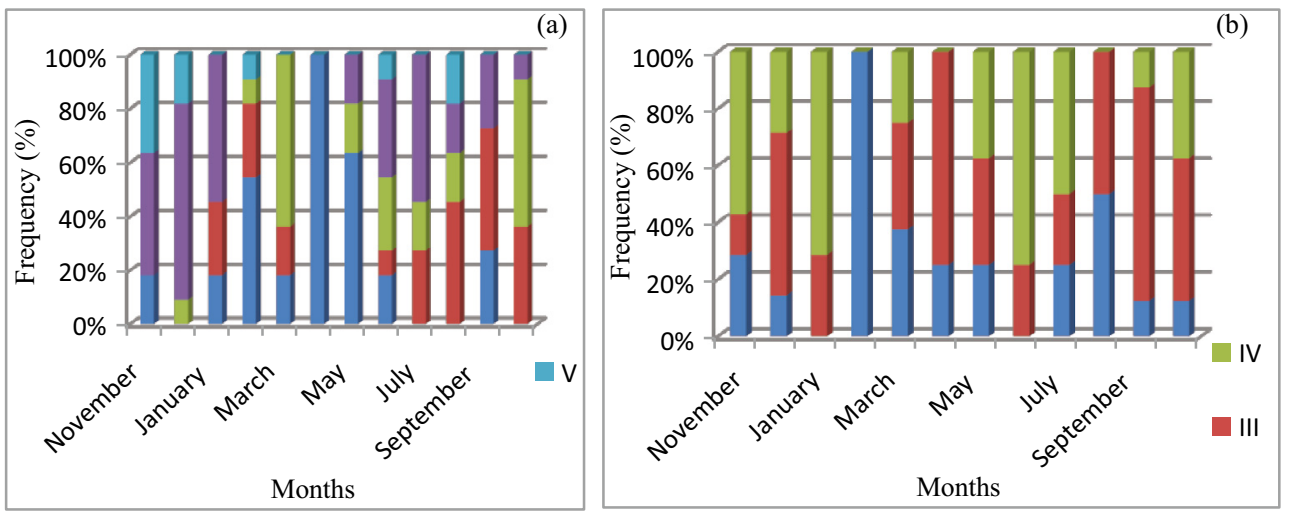

Figure 5: Monthly variations of (a) ovarian and (b) testis maturity stages of $P$. obscura during study period.

[8]). Mean GSI was significantly higher in May, June and January for female, while higher GSI in male was recorded in June and December which implied the peak of spawning activities. This could mean that $P$. obscura spawn mostly during wet season when water level is high and food is more available as advanced by Al-Mahmud et al. [19] in Channa striata and Isangedighi and Umoumoh [10] in P. obscura.

Moreover, the fish being investigated could be said to be iteroparous in spawning in line with the report of Kpogue et al. [4] and Isangedighi and Umoumoh [10]. This spawning behaviour confers special ability on the species to sustain itself in the habitat against overfishing by artisanal fishermen. This study revealed that $P$. obscura converted less than $2.26 \pm 0.86 \%$ of its body mass to gonadal development as against less than $3.35 \pm 1.05 \%$ reported by Isangedighi and Umoumoh [10] and less than $1.96 \pm 0.63 \%$ by Olurin and Savage [11] for P. obscura. Also, GSI for female P. obscura was considerably higher than male as observed by Al-Mahmud et al. [19] and Isangedighi and Umoumoh [10] in channid species. The result also corroborates with Chatzifotis et al. [20], who posited that a greater proportion in female body reserves was usually allocated to the gonads. This study revealed that $50 \%$ of male and female individuals mature at a mean length of $26.5 \mathrm{~cm}$ and $25.4 \mathrm{~cm}$, respectively, 
Table 4: Average fecundity indices (mean $\pm \mathrm{SD}$ ) for P. obscura.

\begin{tabular}{|c|c|c|c|c|c|c|}
\hline \multirow{2}{*}{$\begin{array}{l}\text { Fecundity } \\
\text { indices }\end{array}$} & \multicolumn{6}{|c|}{ Length group $(\mathrm{cm})$} \\
\hline & $15.1-20.0$ & $20.1-25.0$ & $25.1-30.0$ & $30.1-35.0$ & $35.1-40.0$ & $40.1-45.0$ \\
\hline $\begin{array}{l}\text { Average fish } \\
\text { length }(\mathrm{cm})\end{array}$ & $17.5 \pm 1.02$ & $23.1 \pm 1.81$ & $\begin{array}{l}26.8 \pm \\
1.17\end{array}$ & $32.9 \pm 1.23$ & $36.2 \pm 1.44$ & $43.9 \pm 1.32$ \\
\hline $\begin{array}{l}\text { Average fish } \\
\text { weight }(\mathrm{g})\end{array}$ & $\begin{array}{l}50.8 \pm \\
18.14\end{array}$ & $\begin{array}{l}99.6 \pm \\
22.96\end{array}$ & $\begin{array}{l}199.4 \pm \\
44.8\end{array}$ & $\begin{array}{l}358.2 \pm \\
83.34\end{array}$ & $\begin{array}{l}498.6 \pm \\
96.73\end{array}$ & $\begin{array}{l}748.6 \pm \\
53.91\end{array}$ \\
\hline $\begin{array}{l}\text { Average ovarian } \\
\text { weight }(\mathrm{g})\end{array}$ & $2.8 \pm 1.05$ & $3.5 \pm 1.20$ & $5.9 \pm 1.20$ & $7.6 \pm 2.54$ & $\begin{array}{l}11.8 \pm \\
4.97\end{array}$ & $\begin{array}{l}15.6 \pm \\
5.25\end{array}$ \\
\hline $\begin{array}{l}\text { Number of fish } \\
\text { examined }\end{array}$ & 5 & 7 & 16 & 12 & 9 & 5 \\
\hline $\begin{array}{l}\text { Number of ova } \\
\text { per ovarian } \\
\text { weight }(\mathrm{g})\end{array}$ & $\begin{array}{l}262.2 \pm \\
7.73\end{array}$ & $\begin{array}{l}295.1 \pm \\
12.94\end{array}$ & $\begin{array}{l}304.5 \pm \\
16.84\end{array}$ & $\begin{array}{l}323.0 \pm \\
22.53\end{array}$ & $\begin{array}{l}341.9 \pm \\
25.97\end{array}$ & $\begin{array}{l}302.4 \pm \\
27.01\end{array}$ \\
\hline $\begin{array}{l}\text { Relative } \\
\text { fecundity }\end{array}$ & $\begin{array}{l}17.2 \pm \\
11.78\end{array}$ & $10.1 \pm 3.02$ & $9.3 \pm 2.36$ & $6.9 \pm 1.78$ & $7.6 \pm 3.47$ & $6.0 \pm 1.58$ \\
\hline $\begin{array}{l}\text { Absolute } \\
\text { fecundity }\end{array}$ & $\begin{array}{l}753.8 \pm \\
310.06\end{array}$ & $\begin{array}{l}1,037.6 \pm \\
363.1\end{array}$ & $\begin{array}{l}1,829.1 \pm \\
380.84\end{array}$ & $\begin{array}{l}2,478.6 \pm \\
879.48\end{array}$ & $\begin{array}{l}3,806.4 \pm \\
1933.53\end{array}$ & $\begin{array}{l}4,505.0 \pm \\
11.58\end{array}$ \\
\hline
\end{tabular}

Table 5: Relationship between fecundity and morphometric parameters in P. obscura.

\begin{tabular}{lrrrl}
\hline Parameters & $a$ & $B$ & $r^{2}$ & Functional equation $\left(F=a X^{\mathrm{b}}\right)$ \\
\hline Fecundity vs: & & & & \\
Total body weight & 0.800 & 1.363 & 0.753 & $F=0.800(\mathrm{BW})^{1.363}$ \\
Total body length & 2.175 & 0.097 & 0.675 & $F=2.175(\mathrm{TL})^{0.097}$ \\
Ovary weight & 1.105 & 2.403 & 0.982 & $F=1.105(\mathrm{OW})^{2.403}$ \\
Ovary length & 1.926 & 1.983 & 0.794 & $F=1.926(\mathrm{OL})^{1.983}$ \\
Ovary weight vs: & & & & \\
Total body weight & 0.703 & -0.891 & 0.723 & $\mathrm{OW}=0.703(\mathrm{BW})^{-0.891}$ \\
Total body length & 1.903 & -1.992 & 0.643 & $\mathrm{OW}=1.903(\mathrm{TL})^{-1.992}$ \\
\hline
\end{tabular}

which indicate its size at first maturity. The result also showed that female P. obscura matured earlier than male. This finding was consistent with that of Kpogue et al. [4] and Odo et al. [9] who reported $24.5 \mathrm{~cm}$ and $24.7 \mathrm{~cm}$ as length at first maturity for both sexes of P. obscura. According to Moyle and Czech [21], the nature of an environment affects the size of fish at first maturity.

The reproductive cycle of $P$. obscura in this study was classified into five stages as reported for Channa striata (Al-Mahmud et al. [19]). Also, Isangedighi and Umoumoh [10] reported six maturity stages in P. obscura from Itu-Cross River basin. However, Immature (stage I) and spent (stage V) were not encountered in the testicular samples examined in this study. Similar observation was reported by Lawson [22] who investigated maturation and histological 
characteristics of female gonads in mudskipper Periophthalmus papilio from Lagos lagoon. The peak breeding season of $P$. obscura from GSI study supports the current finding on histological observation of gonad. The results obtained on reproductive cycles were very similar to those obtained by Siddiquee et al. [23] in Channa marulius and Isangedighi and Umoumoh [10] in Parachanna obscura.

Based on macroscopic observation, testis colouration did not change much as compared to ovary that turned yellowish-orange on maturation and golden yellow when ready for spawning. A similar phenomenon was reported by Al-Mahmud et al. [19] and Isangedighi and Umoumoh [10]. Information on fecundity and ova diameter progression is useful for quantification of the reproductive capacity of individual fish. Isangedighi and Umoumoh [10] estimated the fecundity of $P$. obscura and reported 328 to 7512 ova, while Olurin and Savage [11] reported 1,711 to 4,000 eggs for the same fish. The estimated absolute fecundity obtained in this study was consistent with the previous findings. However, when compared with the Asian channid Channa striata, fecundity in P. obscura is very low. Narejo et al. [24] reported 3,000 to 12,000 eggs in Channa striata from district Badin, Sindh Pakistan. Marimuthu et al. [25] and Ahyauddin [26] on C. striata reported 3,050 to 12,110 ova from Bangladesh and India. Witthames and Greer walker [27] stated that marked differences in fecundity within species often reflect different adaptations to environmental habitats.

The relationship between fecundity and body length, body weight, ovary weight and ovary length in P. obscura was linear and positively correlated with high predictive value. It was, however, noted that ovary weight was negatively correlated to body length and weight of the fish. A similar phenomenon in channid species was observed by Isangedighi and Umoumoh [10] and Marimuthu et al. [25]. In contrast, Olurin and Savage [11] reported negative correlation between fecundity and body parameters for $P$. obscura. Also in line with the present study, Kpogue et al. [4] reported $1.33 \mathrm{~mm}$ diameter for mature oocytes in P. obscura and Olurin and Savage [11] reported 0.88 to $1.11 \mathrm{~mm}$. Narejo et al. [24] and Marimuthu et al. [25] obtained a diameter range of 0.70 to $1.30 \mathrm{~mm}$ in $C$. striatus. Based on these findings, it could be inferred that oocyte diameters of $1.0 \mathrm{~mm}$ and above can be used as maturity criterion.

\section{REFERENCES}

[1] CIFA., Snakehead Fishes fact sheets. Central Institute of Freshwater Aquaculture, Kausalyaganga, Bhubaneswar-751 002, Odisha, India. Printed at: Capital Business Service and Consultancy B-51, Sahid Nagar, Bhubaneswar. 38pp., 2012.

[2] Sydenham, D.H., A fish tagging experiment in a Nigerian Forest Stream. Revue Zoologique Africaine, 90, pp. 275-292, 1976.

[3] Marimuthu, K., Haniffa, M.A. \& Aminur Rahman, A., Spawning performance of Native threatened spotted Snakehead fish, Channa punctatus (Actinoptergii: Channidae: Perciformes), induced with Ovatide. Acta Ichthyologica et Piscatoria, 39(1), pp. 1-5, 2009.

[4] Kpogue, D.N.S., Mensah, G.A. \& Fiogbe, E.D., Review of biology, ecology and prospect for aquaculture of Parachanna obscura. Reviews in Fish Biology and Fisheries, 23(1), pp. 41-50, 2012.

[5] Malhotra, Y.R., Jyoti, M.K. \& Gupta, K., Ovarian cycle and spawning season of Ophiocephalus punctatus inhabiting Jammu waters, India. Japanese Journal of Ichthyology, 25(3), pp. 190-196, 1978.

[6] Muchlisin, Z.A., Musman, M. \& Siti-Azizah, M.N., Spawning seasons of Rasbora tawarensis in Lake Laut Tawar, Aceh Province, Indonesia. Reproductive Biology and Endocrinology, 8, pp. 49-58, 2010. 
[7] Schlosser, I.J., Environmental variation, life-history attributes, and community structure in stream fishes: implications for environmental management and assessment. Environmental Management, 15, pp. 621-628, 1990.

[8] Roja, S., Biology of Flat Toadfish, Colletteichthys dussumeri (Valenciennes, 1837) of Cochin Estuary. Ph.d. Thesis submitted to the Department of Marine Biology, Microbiology and Biochemistry, Cochin University of Science and Technology, Kerala, India. 334pp., 2011.

[9] Odo, G.E., Onoja, S.U. \& Onyishi, G.C., The biology of Parachanna obscura (Osteichthyes: Channidae) in Anambra River, Nigeria. International Journal of Fisheries and Aquaculture, 4(8), pp. 154-169, 2012.

[10] Isangedighi, I.A. \& Umoumoh, O.E., Some aspects of the reproductive biology of African Snakehead - Parachanna obscura in Itu-Cross river system. Nigerian Journal of Agriculture, Food and Environment, 7(4), pp. 19-30, 2011.

[11] Olurin, K.B. \& Savage O.D., Reproductive biology, length-weight relationship and condition factor of the African snake head, Parachanna obscura, from River Oshun, South-west Nigeria. International Journal of Fisheries and Aquaculture, 3(8), pp. 146150, 2011.

[12] Marino, G.E., Azzuro, A., Massari, M.G., Finoia \& Mandich, A., Reproduction in the dusky grouper from the Southern Mediterranean. Journal of Fish Biology, 58, pp. 909927, 2001.

[13] Bancroft, J.D. \& Gamble, M., Theory and Practical of Histological Techniques. 5th ed., Churchill Livingstone: London, p. 796, 2002.

[14] Nunez, J. \& Duponchelle, F., Towards a universal scale to assess sexual maturation and related life history traits in oviparous teleost fishes. Fish Physiol. Biochem., 35(1), pp. 167-180, 2009.

[15] Suresh, V.R., Biswas, B.K., Vinci, G.K., Mitra, K. \& Mukherjee, A., Biology and fishery of Barred Siny eel, Macrognathus pancalus Hamilton. Acta Ichthyologica et Piscatoria, 36(1), pp. 31-37, 2006.

[16] Farmer, B.M., French, D.J.W., Potter, I.C., Hesp, S.A. \& Hall, N.G., Determination of biological parameters for managing the fisheries for Mulloway and Silver Trevally in Western Australia, Murdoch University, Murdoch Western Australia 6150, Fisheries Research and Development Corporation Report FRDC Project 2002/004, p. 150, 2005.

[17] Douglas, C. Sexual maturity and fecundity of African catfish (Clarias gariepinus) with an observation on spawning behaviour of the Nile catfish, (Clarias lazera), Zoological Journal of the Limnological society of London, 35, pp. 1-45, 1979.

[18] Odo, G.E., Nwamba, H.O. \& Eyo, J.E., Aspect of the Biology of Heterotis niloticus Cuvier 1829 (Osteoglossiformes: Osteoglossidae) in the Anambra flood River system, Nigeria. Animal Research International, 6(2), pp. 994-1002, 2009.

[19] Al-Mahmud et al., Cyclic variations of gonad development of an air-breathing fish, Channa striata in the lentic and lotic environments. Fisheries and Aquatic Sciences, 19(5), pp. 1-7, 2016.

[20] Chatzifotis, S., Muje, P., Pavlidis, M., Agren, J., Paalavuo, M. \& Molsa, H., Evaluation of tissue composition and serum metabolites during gonadal development in the common dentex (Dentex dentex). Aquaculture, 236, pp. 557-573, 2004.

[21] Moyle, P.B. \& Czech, J.J., Fishes: An introduction to ichthyology, 2nd ed. PrenticeHall, Inc.: Englewood Cliffs, N.J., p. 559, 1988. 
[22] Lawson, E.O., Maturation and Histological characteristics of ovaries in Mudskipper, Periophthalmus papilio from Lagos lagoon, Nigeria. Journal of American Science, 6(11), pp. 965-976, 2010.

[23] Siddiquee, A., Rashid, H., Islam, M.A., Ahmed, K.K.U. \& Shahjahan, M., Reproductive biology of great snakehead Channa marulius from sylhet basin in the North East Bangladesh. Journal of Fisheries and Aquatic Science, 10(4), pp. 294-299, 2015.

[24] Narejo, N.T., Jalbani, S. \& Dastagir, G., Breeding biology of snakehead, Channa striatus (Bloch) from District Badin Sindh, Pakistan. Biolife, 3(2), pp. 434-436, 2015.

[25] Marimuthu, K., Kumar, D. \& Haniffah, M.A., Induced spawning and seed production of striped snakehead Channa striatus using ovatide. Journal of Applied Aquaculture, 19, pp. 95-103, 2007.

[26] Ahyaudin, B.A., Aspects of the reproductive biology of female snakehead (Channa striatus) obtained from irrigated rice agroecosystem, Malaysia. Hydrobiologia, 411, pp. 71-77, 1999.

[27] Witthames, P.R. \& Greer Walker, M., Determinacy of fecundity and oocyte atresia in sole (Solea solea) from the Channel, the North Sea and the Irish Sea. Aquat. Living Resour., 8, 91-109, 1995. 